\title{
Marble Powder As Fine Aggregates in Concrete
}

\author{
Muhammad Jaffar Memon \\ Department of Civil Engineering, \\ Mehran University of Engineering and \\ Technology, Shaheed Zulfiqar Ali Bhutto \\ Campus, Khairpur Mirs', Pakistan \\ Jaffar.memon@muetkhp.edu.pk
}

Ashfaque Ahmed Jhatial

Department of Civil Engineering, Mehran University of Engineering and Technology, Shaheed Zulfiqar Ali Bhutto Campus, Khairpur Mirs', Pakistan ashfaqueahmed@muetkhp.edu.pk

\author{
Zaryab Ahmed Rid \\ Department of Civil Engineering, \\ Mehran University of Engineering and \\ Technology, Shaheed Zulfiqar Ali Bhutto \\ Campus, Khairpur Mirs', Pakistan \\ zaryabrid@gmail.com
}

\author{
Touqeer Ali Rind \\ Department of Civil Engineering, \\ Mehran University of Engineering and Technology, Shaheed \\ Zulfiqar Ali Bhutto Campus, Khairpur Mirs', Pakistan \\ touqeerali@muetkhp.edu.pk
}

\author{
Abdul Razzaque Sandhu \\ Department of Civil Engineering, \\ Mehran University of Engineering and Technology, Shaheed \\ Zulfiqar Ali Bhutto Campus, Khairpur Mirs', Pakistan \\ abdulrazzaque@muetkhp.edu.pk
}

\begin{abstract}
Marble industry contributes significantly to the socioeconomic development of any country. Due to the abundance of marble reserves, Pakistan relies on marble industry, which in turn contributes to its GDP. Marble powder (MP), produced from the marble industry is also increasing, which constantly remains a source of hazards to the environment. At the same time, natural sand deposits are decreasing, causing an acute need for a product that matches the properties of sand in concrete. This study has been conducted to demonstrate the possibility of using MP as a replacement of sand in the manufacturing of concrete. The MP was used in 5 different dosage percentages ranging from $0 \%$ to $100 \%$ by weight of sand with an increment of $25 \%$. The effect of MP on the strength behavior of concrete was studied at three different curing ages $(7,14$ and 28 days). It was observed from the results that MP could potentially replace sand up to a certain limit without compromising on strength. It was also noticed that $50 \%$ sand replacement with MP was optimum at which $13.52 \%$ and $35.54 \%$ increase in compressive and flexural strength was achieved compared to the control sample. Based on the results of this experimental study, it is clear that MP can partially be used in place of sand in concrete.
\end{abstract}

Keywords-partial fine aggregates replacement; marble powder; solid waste materials; concrete; natural resources conservation

\section{INTRODUCTION}

Construction industry is vital for the development of a country's economy and infrastructure $[1,2]$. In the modern era, concrete has become the most widely used construction building material in the world [2], due to its availability, flexibility, serviceability and durability $[3,4]$. Concrete is an artificial material comprised of cement, aggregates (fine and coarse) and water. Aggregates represent approximately 60\%$75 \%$ of the total concrete's volume [5], therefore, they play a significant role in the fresh and hardened concrete properties [6]. In construction industry, aggregates obtained from natural resources are utilized in the manufacturing of concrete. Throughout the years, the consumption of concrete throughout the world has reached overwhelming scales. It has been reported that 11.5 billion tons of concrete is consumed every year out of which 9 billion tons of aggregates [7]. The alarmingly high amount of consumption of aggregates has become an environmental concern, depleting natural resources at much faster rate than they are being regenerated.

Due to the natural resource depletion and its negative impact on the environment [8], research has focused on finding alternative materials to be used as aggregates. There are many solid waste materials that have the potential to be used as fine and coarse aggregate replacements. These materials are being generated through agro-industrial processes and are typically disposed-off into landfills causing additional health and environmental issues. This experimental work studies the effect of one such solid waste material, Marble Powder (MP), on the strength properties of concrete when utilized as fine aggregate replacement. Marble is one of the most extensively used types of rock/stone nowadays. It is the end-product of the metamorphism process of sedimentary carbonate rocks, most commonly limestone or dolomite rock [9]. Marble has retained its importance over time, due to its attractive decorative purposes [10] and its variety of appearances and colors. In ancient times, marble was mainly used in sculptures. Nowadays, marble is most likely to be found in and on buildings. Marble has the tendency to withstand elements, and survive for a long time while retaining its look. Marbles are utilized in floors, stairs, walls, counters, sinks and foundations etc. Despite its attractiveness, the powder produced from marble waste has significantly adverse impact on the environment and public health $[11,12]$. MP is a by-product which is typically produced during the sawing and polishing of marble blocks [11]. It has been reported that approximately $25 \%$ of the processed marble is converted into powder form [11]. The production of marble has been increasing, thus the marble powder generation is on the rise as well. Like other waste materials, the disposal of the marble powder has become a serious environmental problem $[13,14]$. The marble industry 
impacts significantly on the socio-economic development of developing countries, such as Pakistan, by providing jobs to thousands of people, as well as contributing to the GDP of the country [15]. According to TDAP [16], it is estimated that Pakistan has marble reserves of approximately 300 billion tons, mainly in three provinces (Khyber Pakhtunkhwa, Punjab and Baluchistan). The finally generated waste material (MP) is usually dumped at open grounds. With industrial growth, waste has also tremendously grown which is a serious threat to the environment and people. So, to overcome this serious problem we can use several types of waste coming from the industry, e.g. by replacing or partially replacing the constituents of concrete (cement, sand or aggregates) thus conserving natural resources. Marble industry is producing a huge amount of waste. As a fine aggregate which is very important component of concrete, natural river sand is mostly used. Marble waste can be utilized in various ways and marble slurry can be used as fine aggregates in concrete replacing, at least partially, river sand. The utilization of marble dust powder (MDP) as cement replacement was studied in [12]. The cement was partially replaced with MDP up to $20 \%$ by weight with an increment of $5 \%$. It was determined that $10 \%$ to $15 \%$ MDP achieved maximum higher strength compared to control sample, suggesting that MDP could be potentially be used as supplementary cementitious material, reducing the cement content in concrete. Authors in [17] also conducted an experiment on MP as partial cement replacement. Their findings agreed with [12], determining $10 \%$ to be the optimum replacement. The MP has been reported to be used as partial cement replacement in [18-20], with the optimum dosage ranging from $5 \%$ to $15 \%$. Though MP has been studied by various researchers as partial cement replacement material, the study on the utilization of MP as fine aggregate replacement is limited to certain dosage, maximum $50 \%[9,19,21,22]$. Therefore, in this experimental work, the effect of MP as fine aggregates on the strength properties of concrete is studied.

\section{RESEARCH METHODOLOGY}

\section{A. Materials}

In this study, the mix ratio of 1:2:4 was utilized with watercement ratio of 0.55. Marble waste was obtained from the Karachi Marble factory situated in Khairpur Mirs', Pakistan. To achieve MP, the obtained marble waste was crushed into powder form. The fine aggregates were replaced using MP from $0 \%$ to $100 \%$ with an increment of $25 \%$ as shown in Table I. The MP chemical composition is shown in Table II.

\section{B. Experimental Procedure}

To determine the effect of MP on the strength properties of concrete, when utilized as fine aggregate, cubes of $150 \mathrm{~mm}$ dimension were cast and tested for compressive strength according to ASTM C39/C39M-18 [24]. Also, beams of $100 \mathrm{~mm} \times 100 \mathrm{~mm} \times 500 \mathrm{~mm}$ were cast and tested for flexural strength in accorance to ASTM C78/C78M-18 [25]. Every batch contained 3 cubes and 3 beams. The concrete was taken out of the moulds after $24 \mathrm{~h}$ and was taken for curing. After the curing process, the specimens were tested at the age of 7,14 and 28 days to check the strength at different ages.
TABLE I. MIX PROPORTIONS

\begin{tabular}{|c|c|c|}
\hline Mix Proportion Name & Sand (\%) & Marble (\%) \\
\hline MP0 & 100 & 0 \\
\hline MP25 & 75 & 25 \\
\hline MP50 & 50 & 50 \\
\hline MP75 & 25 & 75 \\
\hline MP100 & 0 & 100 \\
\hline
\end{tabular}

TABLE II. MP VS NATURAL AGGREGATES COMPOSITION [23]

\begin{tabular}{|c|c|c|}
\hline Component & Marble waste (\%) & Natural aggregates (\%) \\
\hline $\mathrm{LOI}$ & 45.07 & 5.08 \\
\hline $\mathrm{SiO}_{2}$ & 3.75 & 53.7 \\
\hline $\mathrm{CaO}$ & 33.12 & 4.83 \\
\hline $\mathrm{MgO}$ & 17.91 & 2.01 \\
\hline $\mathrm{Fe}_{2} \mathrm{O}_{3}$ & 0.13 & 10.66 \\
\hline $\mathrm{Al}_{2} \mathrm{O}_{3}$ & Traces & Nil \\
\hline Sulphate content & Nil & Nil \\
\hline
\end{tabular}

\section{RESULTS AND DISCUSSION}

\section{A. Compressive Strength}

The results of average compressive strength tests of concrete incorporating MP as fine aggregate replacement are shown in Table III. MP25 and MP50 showed increase in comparison with control (MP0). However, as the percentage of MP increased to $75 \%$ and $100 \%$, the samples showed a decline in compressive strength. The rise was observed to be $13.52 \%$ on MP50 while declination of $28.22 \%$ was noted at MP100 in comparison to control. The results are in line with the findings in [26-28]. Powdered material contains the characteristic of a filler thus could increase the strength of concrete up to a certain level. It can be said that the desired result can be achieved in concrete with smaller amounts of MP, due to its filler role, because slight increments in the total amount of cement help achieving the targeted compressive strength levels.

TABLE III. CONCRETE AVERAGE COMPRESSIVE STRENGTH

\begin{tabular}{|c|c|c|c|}
\hline \multirow{2}{*}{ Mix } & \multicolumn{3}{|c|}{ Compressive Strength (MPa) } \\
\cline { 2 - 4 } & 7 Days & 14 Days & 28 Days \\
\hline MP0 & 23.53 & 28.43 & 31.80 \\
\hline MP25 & 25.69 & 30.81 & 34.20 \\
\hline MP50 & 27.08 & 32.54 & 36.10 \\
\hline MP75 & 22.45 & 26.66 & 29.96 \\
\hline MP100 & 18.37 & 22.29 & 24.80 \\
\hline
\end{tabular}

\section{B. Flexural Strength}

The average flexural strength of concrete incorporating different percentages of MP as fine aggregates is shown in Table IV. The behavior of concrete flexural strength is similar to that of its compressive strength with the incorporation of MP. Samples containing $25 \%$ and $50 \%$ of MP showed gain in flexural strength compared to the control sample, a maximum of $35.54 \%$ increase was noticed at $50 \%$ replacement. Further increase in MP resulted in decline on all curing stages, suggesting that the optimum replacement is $50 \%$. The decline in strength can be attributed to the granular surface of the MP which is exposed as the crack developed under the load [29]. The samples containing 75\% MP (MP75) showed the least decline of $4.27 \%$ in strength, which could also be utilized taken into account the rapid rate of depletion of natural resources. 
TABLE IV. CONCRETE AVERAGE FLEXURAL STRENGTH

\begin{tabular}{|c|c|c|c|}
\hline \multirow{2}{*}{ Mix } & \multicolumn{3}{|c|}{ Flexural Strength (MPa) } \\
\cline { 2 - 4 } & 7 Days & 14 Days & 28 Days \\
\hline MP0 & 3.47 & 4.12 & 4.22 \\
\hline MP25 & 4.14 & 4.90 & 5.47 \\
\hline MP50 & 4.31 & 5.05 & 5.72 \\
\hline MP75 & 3.14 & 3.46 & 4.04 \\
\hline MP100 & 2.96 & 3.42 & 3.93 \\
\hline
\end{tabular}

\section{CONCLUSION}

The conclusions that can be drawn from the results of our experimental work are:

- Compressive strength of concrete tends to increase initially with increasing replacement percentage up to an optimum limit, but then it continuously decreases.

- Flexural tensile strength did also show similar trend. It continually increases up to an optimum limit, and from there it decreases.

- The optimum limit for MP was observed to be $50 \%$ replacement of sand where it resulted in $13.52 \%$ and $35.54 \%$ increase in compressive and flexural strength of concrete respectively in comparison with the control sample.

- The strength gain of concrete when sand was partially replaced with MP showed that it can be effectively utilized in the manufacturing of concrete and thus contribute to the reduction of natural resources utilization in concrete.

\section{REFERENCES}

[1] A. A. Jhatial, S. Sohu, N. K. Bhatti, M. T. Lakhiar, R. Oad, "Effect of Steel Fibres on the Compressive and Flexural Strength of Concrete", International Journal of Advanced and Applied Sciences, Vol. 5, No. 10, pp. 16-21, 2018

[2] S. Sohu, K. Ullah, A. A. Jhatial, M. Jaffar, M. T. Lakhiar, "Factors Adversely Affecting Quality in Highway Projects of Pakistan", International Journal of Advanced and Applied Sciences, Vol. 5, No. 10, pp. 62-66, 2018

[3] S. E. Aprianti, "A Huge Number of Artificial Waste Material Can Be Supplementary Cementitious Material (SCM) for Concrete Production-a Review Part II", Journal of Cleaner Production, Vol. 142, pp. 41784194, 2017

[4] A. A. Jhatial, W. I. Goh, K. H. Mo, S. Sohu, I. A. Bhatti, "Green and Sustainable Concrete-The Potential Utilization of Rice Husk Ash and Egg Shells", Civil Engineering Journal, Vol. 5, No. 1. pp. 74-81, 2019

[5] A. R. Sandhu, M. T. Lakhiar, A. A. Jhatial, H. Karira, Q. B. Jamali, "Effect of River Indus Sand and Recycled Concrete Aggregates as Fine and Coarse Replacement on Properties of Concrete", Engineering, Technology \& Applied Science Research, Vol. 9, No. 1. pp. 3831-3834, 2019

[6] C. S. Poon, Z. H. Shui, L. Lam, H. Fok, S. C. Kou, "Influence of Moisture States of Natural and Recycled Aggregates on the Slump and Compressive Strength of Concrete", Cement and Concrete Research, Vol. 34, No. 1, pp. 31-36, 2004

[7] S. Singh, R. Nagar, V. Agrawal, "Feasibility as a potential substitute for natural sand: a comparative study between granite cutting waste and marble slurry", Procedia Environmental Sciences, Vol. 35, pp. 571-582, 2016

[8] A. A. Jhatial, W. I. Goh, N. Mohamad, S. Sohu, M. T. Lakhiar, "Utilization of Palm Oil Fuel Ash and Eggshell Powder as Partial Cement Replacement-A Review”, Civil Engineering Journal, Vol. 4, No. 8, pp. 1977-1984, 2018
[9] R. Malpani, S. K. Jegarkal, R. Shepur, R. H. N. Kiran, V. K. Adi, "Effect of Marble Sludge Powder and Quarry Rock Dust as Partial Replacement for Fine Aggregates on Properties of Concrete", International Journal of Innovative Technology and Exploring Engineering, Vol. 4, No. 1, pp. 39-42, 2014

[10] G. C. Ulubeyli, R. Artir, "Properties of hardened concrete produced by waste marble powder", Procedia-Social and Behavioral Sciences, Vol. 195, pp. 2181-2190, 2015

[11] N. M. Soliman, "Effect of using Marble Powder in Concrete Mixes on the Behavior and Strength of R.C. Slabs", International Journal of Current Engineering and Technology, Vol. 3, No. 5, pp. 1863-1870, 2013

[12] R. Kumar, S. K. Kumar, "Partial replacement of cement with marble dust powder", International Journal of Engineering Research and Applications, Vol. 5, No. 8, pp. 106-114, 2015

[13] M. Y. Celik, E. Sabah, "Marble Deposits and the Impact of Marble Waste on Environmental Pollution Geological and technical characterization of Iscehisar (Afyon-Turkey)", Journal of Environmental Management, Vol. 87, pp. 106-116, 2008

[14] K. E. Alyamac, R. Ince, "A preliminary concrete mix design for SCC with marble powders", Construction and Building Materials, Vol. 23, No. 3, pp. 1201-1210, 2009

[15] Q. Khan, S. Maqsood, S. B. Khattak, M. Omair, A. Hussain, "Evaluation of Activity Hazards in Marble Industry of Pakistan", International Journal of Engineering \& Technology, Vol. 15, No. 5, pp. 73-78, 2015

[16] M. A. Korai, S. Hussain, A. J. Abro, A Report on Marble \& Granite, TDAP, 2017

[17] R. Chandrakar, A. Singh, "Cement Replacement in concrete with Marble Dust Powder", International Research Journal of Engineering and Technology, Vol. 4, No. 5, pp. 1409-1411, 2017

[18] A. Ergun, "Effects of the usage of diatomite and waste marble powder as partial replacement of cement on the mechanical properties of concrete", Construction and Building Materials, Vol. 25, pp. 806-812, 2011

[19] A. A. Aliabdo, A. E. M. Abd Elmoaty, E. M. Auda, "Re-use of waste marble dust in the production of cement and concrete", Construction and Building Materials, Vol. 50, pp. 28-41, 2014

[20] C. Vaidevi, "Study on marble dust as partial replacement of cement in concrete", Indian Journal of Engineering, Vol. 4, pp. 14-16, 2013

[21] R. Baboo, N. H. Khan, K. Abhishek, R. S. Tabin, S. K. Duggal, "Influence of Marble powder/granules in Concrete mix", International Journal of Civil and Structural Engineering, Vol. 1, No. 4, pp. 827-834, 2011

[22] H. Binici, H. Kaplan, S. Yilmaz, "Influence of marble and limestone dusts as additives on some mechanical properties of concrete", Scientific Research and Essays, Vol. 2, No. 9, pp. 372-379, 2007

[23] S. D. Kore, A. K. Vyas, "Impact of marble waste as coarse aggregate on properties of lean cement concrete", Case Studies in Construction Materials, Vol. 4, pp. 85-92, 2016

[24] ASTM C39/C39M-18, Standard Test Method for Compressive Strength of Cylindrical Concrete Specimens, ASTM International, 2018

[25] ASTM C78/C78M-18, Standard Test Method for Flexural Strength of Concrete (Using Simple Beam with Third-Point Loading), ASTM International, 2018

[26] M. Vijayalakshmi, A. S. S. Sekar, G. G. Prabhu, "Strength and durability properties of concrete made with granite industry waste", Construction and Building Materials, Vol. 46, pp. 1-7, 2013

[27] A. M. Rashad, "A preliminary study on the effect of fine aggregate replacement with metakaolin on strength and abrasion resistance of concrete", Construction and Building Materials, Vol. 44, pp. 487-495, 2013

[28] K. E. Alyamac, A. B. Aydin, "Concrete Properties Containing Fine Aggregate Marble Powder", KSCE Journal of Civil Engineering, Vol. 19, No. 7, pp. 2208-2216, 2015

[29] M. Singh, K. Choudhary, A. Srivastava, K. S. Sangwan, D. Bhunia, “A study on environmental and economic impacts of using waste marble powder in concrete", Journal of Building Engineering, Vol. 13, pp. 8795,2017 